\title{
音読の聞きやすさと超分節的側面
}

\section{A coustic Correlations of Suprasegmental Features and the Easiness of Hearing of Oral Readings}

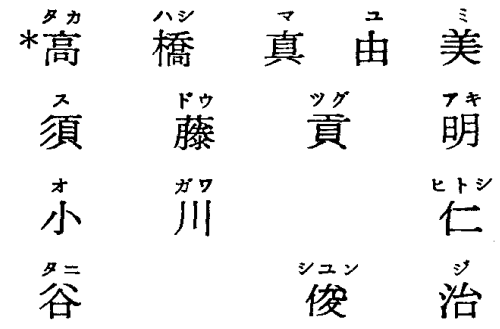

(東京学芸大学)

言語の超分節的側面は言語認知にとって、重要な役割を果していると考えられる。この研究では、1．聞きや すさに対して心理的な尺度があるかどうか、2. 心理的な尺度はどのような超分節的側面で客観的に表わされう るか、3． 音韻が伝える意味の分節と、超分節的側面は対応するかどうかを求めることによって、聴覚、言語障 害児に与える言語刺载のなかに超分節的側面を含める必要があるかどかを考察することを目的とした。読み の5まさの異なる 8 人の読み手の10分間の音読を、聞き手に聞きやすさについて一対比較で判断させ、音群、休 止、基本周波数の分析、および句構造と休止の関係を測定した。その結果、心理的な聞きやすさと超分節的な側 面之の対応は高く（rs=.95）また、超分節的側面は意味の符号化を容易にしていると考えられた。よって、超 分節的側面を考慮に入れた言語刺戟の与え力をする必要があると考え得た。

\section{I はじめに}

相手に聞きやすく話すことは、コミュニケーションを 円滑にする一要因であると考えられる。聞きやすさは、 意味、話題、構文、音調などを総合して判断される心的 過程であると考えると、この聞きやすさの研究には構文 や単語の意味などの分節的側面を主とする方法と、音調 (イントネーション) や休止等の超分節的側面から研究 する方法とがあると考える。

P. Menyuk 1)は、文を話す以前の子供の文様（Sentence like) の発話 の中で、知問文、感嘆文等のイン トネーションが表われること、および、語順を倒置した 文章 (reverese word order sentence) に対してイント ネーションを付加したときにも、年少児の方が年長览よ りも反復する率が高いことから、幼児の言語学習の順序 は音調規則に始まると主張している。このことから、言 語学習に関する研究の基礎条件として、音声言語の超分
節的側面の統制が考慮されなくてはならないと考光得 る。しかし、Menyuk のとった方法は観察によるもの であり、科学的な測度に久けている。さらに、音声言語 のどのような側面が音声規則を構成しているのか不明で あるし、どのような要素が音声言語の聞きやすさや、言 語学習に関係しているのか明示していない。したがっ て、言語指導に、音声のどのような要素が関連するのか 不明である。そこで、言語指道の際に関連すると考えら れる音声の超分節的側面を取り上げ、その5ちの、どの ような物理的な要素を考える必要があるかを考察した。

比企 2)は合成音声の立場から、聞きとりやすさは、休 止が一つの決定要因になると述べ、朗読の時間と休止の 持続時間などの物理的な分析をしている。GoldmanEisler 3)は自発的な発話の休止を測定し、くり返し同じ 内容を話させた場合は、回数を重ねるにしたがって、休 止の持続時間が減るのに対して、逆に要䄪や意図などを

* 現在 神奈川県平塚市立崇善小学校併設幼児ことばの教室 
説明する時には休止の持続時間が虔くなることから、 休止は思考の深さと関係があると述べている。また、 P. Lieberman 4) は、休止の位置や持続時間の特徵を変 えることによって、あいまいな文の文法的構造が明確に なり、むい来いさが減ることを、話しコトバの物理的解 析から推定している。

また、篗者らはイントネーションも疑間文、感嘆文、 平叙文などの文法的なカテゴリーを指分5)したり、感情 などの情報を后達することを郝告6) し态。すなわち、 平叙文で裂かれた文章にイントネーションをつけて棓さ せ、疑閭文、平叙文、感嘆文に $90 \%$ 受け取られる可能性

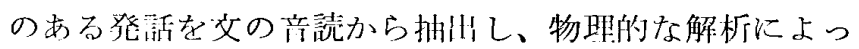
て、イントネーション(=基本周波数)のつけ方に差があ ることを明らにした。さらに、等者等6)扣よび、Williams 等 7)は、小劇の朗読による感情の表現を物㽢的に解析す ることによって、感情表現が其本周波数の特微と結びつ いていることを示している。

これらの砳究から、休止によって句切られた音群は一 倜のコミュニケーションの単位を構成し、音群と休止が 一つの規则体系の中にあって、ためらいなどの情緒的、 および棓語学的な情報を加えると仮定した。すなわり、 読み手が、文の意味を理解して、相手汇伝澾しょうとす る時には、休止やイントネーションあるいは音群の持続 時間と変化のし万に敒意の操作が加わると仮定した。し たがって、じょうずな音読以よる音声の連続体は読む人 の意味解釈の結果であり、それはイントネーションやそ の持続時間としての音群、战よび休止の超分節的側面の 行要素にも表出されると考光た。すなわら、我々が日常 のコミュニケーションにどのような超分節的要素をもっ た音声言話を川いているかを购ることから、言語指導の 場に抢いて、どの程度の長さの構文や、イントネーショ ンの変化、休止の時間が適当であるか否かを、音読の良 し悪しから考察を進め得ると考えた。さらに、超分節的 要素が音声言語を認識するためのどの上うな情報の媒休 となっているかを推察できると考えた。

これらを明示するために、物理的な解析と闹時に、聞 きやすさを心理的に测定し、物理的に測定される音群と 休止招よびイントネーションとの関係を求めることを必 要とした。この研究では、聞きやすさに関係すると考兄 られる要菜として音群、休止、イントネーションを選ん で物理的分析をした結果之、聞きやすさの聴取実験の結 果と阘係があるか否かを検討した。そのために、音読の うまさが異なると考えられる読み手を選んで、各読み手 の蓄読の聞きやすさの順位を一対比較法に上って求め、

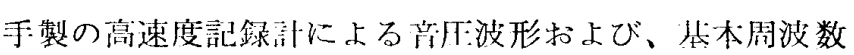

の波形から求められた、音群と休止扣よびイントネーシ ョンの特性について、聞きやすい音読と開きにくい音読 を比較した。つぎに、このよ5にして求められた超分節 的要素と分節的要素の比較をした。その結果から、音声 言語の聞きやすさが超分節的側面とどのように関連する かを知ることを目的とした。さらに、このような超分節 的侧面が分節的倒面々関係しているか不かを聞きやすさ

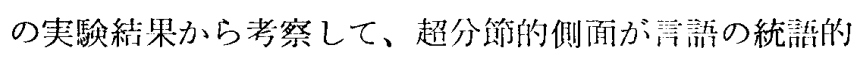
侧面と関連するか愿かを推祭することを目的とした。

\section{II 方 法}

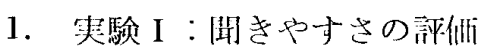

藤㖄 8)は読及手の音声の特微から聞きやすさを分析し た䂤坣を報告している。しかし、聞き手の側が判䉼した 闻きやすさと、物理的特徽から導き山した聞きやすさと が対応しているかよ゙うかは、開き手の侧の分析が無いの で何ともい党ない。木砳究では、そうした研究方法は:の 欠点を補万手続きとして、「聞きやすい」という用語で 反応を求められたときの聞き手の反応に、無作為なバラ つきが無ければ、共通の聞きやすさの测度を判断筫淮と して持っていると仮定することにした。そして、この聞 きや寸さの判断は、はじめに述べたように、装声の超分 節的側面と関係があると仮定されるため、これらの超分 節的要素から成るパターンによって判断されると仮定し た。この手続きと物理的測度との対匛によって、人閒の 内観を頼りにしないで、聞きやすさが客観的に求められ るかどうかを探る一手段とした。

1-1手続き

禑価者に、2 人の読及手が読んだ同一文の聴取材料を 聞かせ、それらの読み手のう台、聞きやすいと判断した 読み手の方に丸印をつけさせた。各読み手に対して与光 られた丸を 1 点とし、読み手別に総合点を計算し、聞き やすさの順位を決めた。聴取材料の刺戟対の作り方は一 対比較法の手続きによった。その結果、反応項日数は読 み手が 8 人であったため、一試行当り 28 項目となった。 また、聞かせる部分によって、聞きやすさの変動がある かどらかを確かめるために、材料とする音読の抽出筒所 を 2 䉯所とし、聴取実験を 2 度行なった。第 1 回めのテ ストと第 2 回めのテスト間隔は学翼効果を消去あるいは 柽減するために 3 日以にとした。

\section{1-2 聴取材料}

読み手が10分間朗読した「星の王子さま」（サン・テ イグジュペリ作 内藤䨆 訳) の冒頭の部分から、比較 的情緒的な表現の部分と、比較的中性的な表現の部分と 判䉼される文音を選んで30 50秒間の音声を抽师した。 その時、聞き手がききやすさを判断する際、なるべく丵 
交等による判断の変動を少なくするため、標本とする文 章を統一した。読み手によって音読時間が異なったの で抽出時閒も異なった。ここで用いた情緒的な文章を Table 1-aにあげた。比較的中性的な交章在 Tabie 1 -. らにあげた。

Table 1-a A list of sentences used to make subjects judge the easiness of hearing and to analyse fundamental frequency

「これ、ヨボヨボじゃないか。列く長生きするヒツジ が注しいんだよ。」

ぼくは、も5がまんしきれなくなってきました。それ に、モーターのとりはずしをいそいでいたので、大ざっ ぱにこんな絵をかきました。

「こいつあ箱だよ。あんたの汪しいヒッジ、その中に いるよ」

ぶっきらぼうにそういいましたが、見ると、ぼっちゃ んの顔が、ぱっと明かるくなったので、添くは、ひどく めんくらいました。

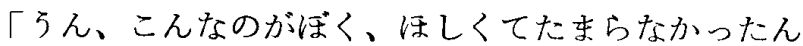
だ。このヒツジ、たくさん草たべる？」

「どうして?」

「だって、注くんとこ、汪んとにちっぽけなんだも の......

Table 1-b A list of sentences used to make subjects judge the easiness of hearing.

そこで、ぼくは、しかたなしに、べつに職をえらん で、飛行機の操縦を括淩えました。そして、世界じゅう を、たいてい、どこも飛んであるきました。なるほど、 地理は、たいそうぼくの役にたちました。涪くは一日 で、シナとアリゾナ州の見わけがつきました。夜どこを 飛んでいるか、わからなくなるときなんか、そういら勉 強は、たいへんためになります。

ぼくは、そんなことで、そうこうしているうちに、た くさんのえらい人たちと、あきるほど近づきになりまし た。長いこと、おとなたちのあいだで、くらしました。 扮となたちのようすを、すぐそばで見ました。でも、将 くの考完は、たいしてかわりませんでした。

\section{1-3 被 験 者}

聴取実験の評优者：各问とも、聞き取りテストの評侀 者は、いづれも健聴で知的に正常な日本人大学生で、男 性と女性を合わせて7名であった。

材料の読み手：読み手は、専門アナウンサー1名、游
専門アナウンサー（アナウソサー養成所の学生）2名、 学生 5 名であった。また、読及手の年秢は統制しなかっ たが、基本周波数の分析の都命はすずてて男性としだ。

\section{1-4, 実験装置}

スタジオ怙よび防音空でマイクロホン（Sony F-26） を通し、テープレコーダ (Sony 707) に録产し、同一 のテープレコーダで絊集し再生しだ。

\section{2. 実験 II：超分節似侧面の分析}

聞きやすく話寸という能力を、聞き手のもっている棈 文体系やファミリアリティのあるイントネーション等を

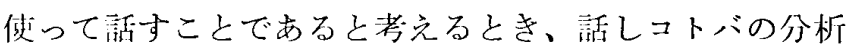

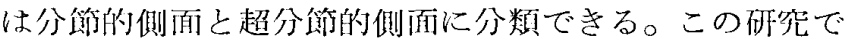
は、聞きやすさに超分節的側面が明確に関係するか否か の検討が主であるところから、それを規定する物理的要 网の抽帅のための条件を整劣るために、材料となる文部 を統一し、分析した。

\section{2-1 分析材料}

音群・休止の持続時間の分析：音群・休止の特徵を度 数分布によって予測しよ弓としたため、ある程度多量の 音群・休止の出現を観察する必要があった。そこで、冬 范み手による10分間の音読を分析の対象とした。音読に 用いた文章は「星の王子様」の冒頭の部分であった。こ の文章の中に、䁷本周波数を分析した辛読部分をも含ん だ。

基本周波数の分析：聞き手に聞きやすさを判断させた 2 種の音読のうち、より情緒的な表現を含んでいると判 断された文章 (Table 1-a) を分析した。なぜならば、 感情とイントネーションが結びついている67)ことを考 虑すれば、感情伝達上の効果は有意なイントネーション の变化之対応すると考えられるので、情緒的な文章を標 本とした方が、聞きやすく話す人と、聞きにくく話寸人 の差を一層明確にしやすいと思われたからであった。

\section{$2-2$ 测 度}

これまでの研究から、超分節的側面の㚏別的素性は、 辛群と休止の持続時間、ピッチおよび音圧であることが 認められている9)。ここでは提示平均音圧をほぼ一定に し、音群、休止の持続侍閒拉よび基本周波数を物理的要 素として分析した。

\section{2-3 各測度の物理的分析方法}

分析の手順を以下のように2つにわけて行なった。

音群と休止の持続時間：筆者10)はさきに音群と休止 のパターンが音読か談話かを乔別する要因となり得る ことを報告したが、ここでは、さらに、音群の持続時間 や休止:の持続特間が、聞きやすさを判断する手がかりと なり得るかどうかるみるために、音読と休忖の持続時間 
と聞きやすさの関係を検討した。

まず、音压波形から、波の部分を音群とし、值線の部 分は休止として分類した。それらの持続時間を測定し、 度数分布をとった。このとき、音群と休止の分類を䛊ら ないように、波形と星韻とのマッチングを行ない、促音 のように音王波形が休止と同じパターンを示している所 は音群に含めた。それ以外は、測定単位として、記述言 語学的な単位は用いなかった。また、休止は音王波形の 直線部分が、 $200 \mathrm{msec}$ 以上続く所とした。測定の単位 時閐は、 $300 \mathrm{msec}$ とした。Fig. 1 に、分析した音声の 音压波形と音群・休止の分類の例を示した。

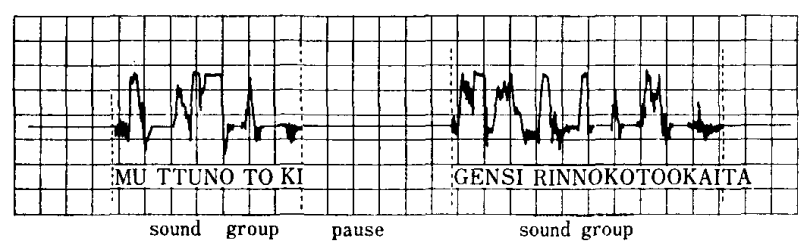

Fig. 1 An example of wave form of speech classified into sound group and pause.

基本周波数：藤田 8)はアナウンサーの高低抑掦がアナ ウンスの習熟度と対応することを報告している。彼は、 $7 \mathrm{msec}$. 每に基本周波数を抽出して、音の高さの使用頻 度の分布および、变動量から、読み手の発話時のピッチ の安定性を考察して、素人と専門家の大まかな分類を試 みた。本砛究では、7 msec. 毎に基本周波数を抽出する 代りに、基本周波数の分析測度として、茥本周波数の变 化幅 6)、平均速度 5)、ピーク数 6)を用いた。すなわら、 手慗のピッチスケーラによる音群ごとに基本周波数波形 を折線近似し、その最大值と最小值の差を変化幅、下降 する基本周波数の絶対值と上昇する基本周波数の和を音 群の持続時間でわることによって1秒当りの周波数の変 化を求めたものを平均速度、山の数をピーク数として、 各测定值を得た。測定值は执〉よそ意味の句切りと考兄 られる音群を単位として算出した。Fig. 2 に基本周波数 の波形の一例と测定值の計算例を示した。

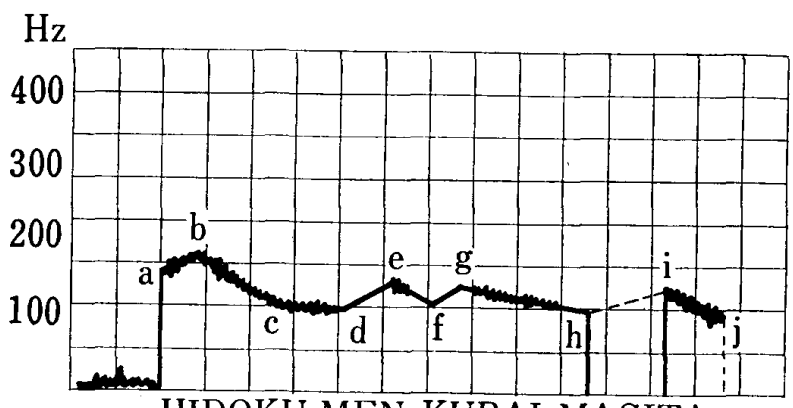

HIDOKU MEN KURAI MASITA

Fig. 2 An example of wave form analysed number of peak, range, and mean rate of Fo contour in ramps. alphabet; value of fundamental number of peak $=4 ; \mathrm{b}, \mathrm{e}, \mathrm{g}, \mathrm{i}$. frequency. range $=80 \mathrm{~Hz} ;(\mathrm{b}-\mathrm{j}) \mathrm{Hz}$. mean rate of Fo contour in ramps $=$ $230 \mathrm{~Hz} / \mathrm{sec}$; $(\mathrm{b}-\mathrm{a})+(\mathrm{b}-\mathrm{c})+(\mathrm{c}-\mathrm{d})+(\mathrm{e}-\mathrm{d})$ $+(e-f)+g-f)+(g-h)+(i-j)) /$ duration of sound group

2-4 湘定機器

(1) 音群および休止の持絖特閒 テープレコーダ (Sony 707)

手製の音生涪

ペンオシログラフ（レクチホリー8 S )

な招記録速度は $5 \mathrm{~cm} / \mathrm{sec}$ 、であった。

(2) 基本風波数:

テープレコーダ (Sony 707)

手製のピッチスケーラ(周波数 range $80 \mathrm{~Hz} \sim 400 \mathrm{~Hz}$ ) ペンオシログラフ (レクチホリー8 S )

な招記錄速度は(1)と同様 $5 \mathrm{~cm} / \mathrm{sec}$.であった。

3. 実験 III：分節的側喕の分析

超分節的な測度が、聞きやすさとどのよ5な测係をる っているかを明らかにするために、奏駼 II では、分筫们 な考察はしなかった。しかし、聞きやすさの判断は、心 理的には意味内容も加えて行なわれていると将えられ る。したがって、もし、超分節的な侧面が分節的な侧闻 と関係が篦いならば、言語指導に超分節的な测度を川い、 ることは意味がないと考える。このことから、超分命们 な側面が、聞さやすさを規定する、で、分節的側面と而。

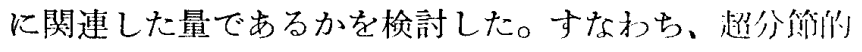

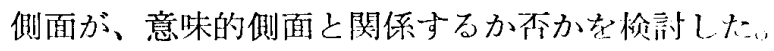

3-1 分析材料

実験 II（基本㓮波数の分析）に朋いたものに四に、上 り情緒的な表現を含む文音の音読を材料とした。

3-2 测度と測定方法

休止は文の句切りを指定し、文の統語的な棈造怒吅碓 にすることが、比企 2)やP、Lieber man 4）の䃘究から 示唆されたので、休止の持続時間を测度とした。休川:が 文・文節・名詞句・接続詞の5ち、どの位罱で、どの和! 度の屒さの持続時間で生じたかを観察した心

$3-3$ 测定機 器

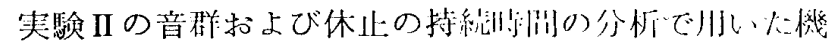
㭜と同じであった。

\section{III 結果と考察}

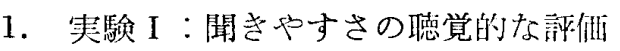
この研究では、聞きやすさを規定している物理的要装 


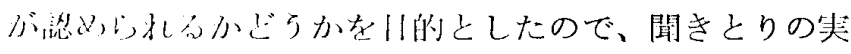

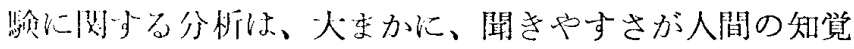

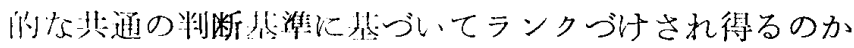
に゙うかに片めた。

対北校珐:で时さとりの似优をさせた結果をもとに、

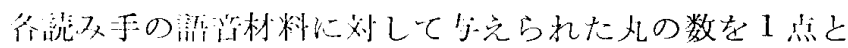

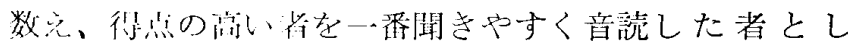
た。束た、行泙倠名によるそれぞれの読み手に対する順

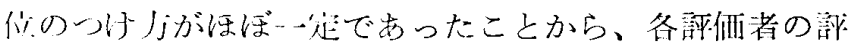

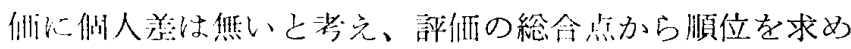
た。Table 2 に、1间めと 2 四めの聞きとりの話者別の

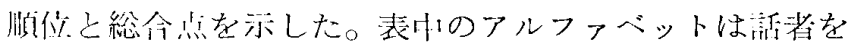
示し、数字は聞きや导さの評优を示す。順位が高いほど 聞きすいと判断された者である。1回めと2回めの顺 位の相则は $\mathrm{rs}=.93$ 之湍い值が得られた。しかし、低い

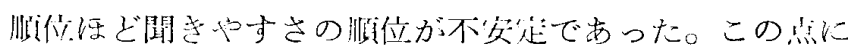
つ、て快後に物理的な分析との闒係で考察する。

\section{Table 2}

\begin{tabular}{|c|c|c|c|c|c|c|c|c|c|}
\hline \multicolumn{2}{|c|}{ speaker } & $A^{* *}$ & $\mathrm{~B}^{*}$ & $\mathrm{C}$ & $\mathrm{D}^{*}$ & $\mathrm{E}^{*}$ & $\mathrm{~F}^{*}$ & $\mathrm{G}^{*}$ & $\mathrm{H}^{*}$ \\
\hline \multirow{2}{*}{ first } & rank & 1 & 2 & 3 & 4 & 5 & 6 & 7 & 8 \\
\hline & $\begin{array}{l}\text { total } \\
\text { score }\end{array}$ & 46 & 38 & 36 & 21 & 16 & 17 & 12 & 10 \\
\hline \multirow{2}{*}{ second } & rank & 1 & 2 & 3 & 4 & 5 & 7 & 8 & 6 \\
\hline & $\begin{array}{l}\text { total } \\
\text { score }\end{array}$ & 48 & 42 & 30 & 28 & 18 & 10 & 5 & 15 \\
\hline
\end{tabular}

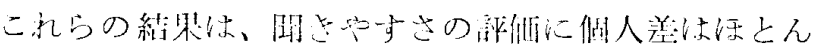

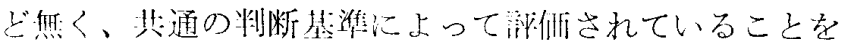

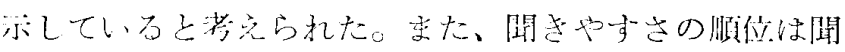

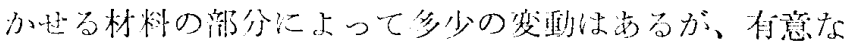

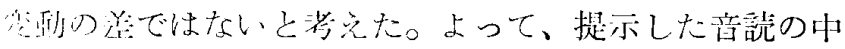

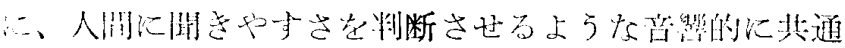
なバターンがすることが想された。

2. 可䮖II：退分邻的側面の分析

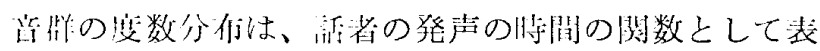

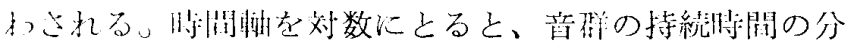

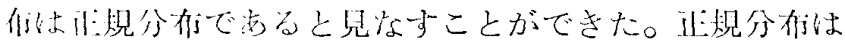

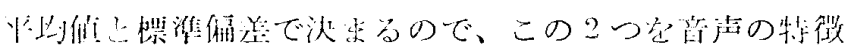
として我好たのが Table 3-1で亦る。この結果による

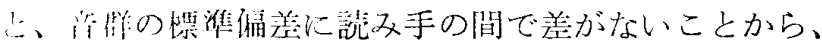

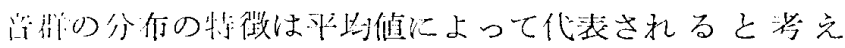

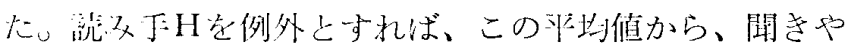

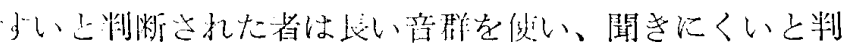

断された者は短かい音群を优う倾向があった。よって、 聞きにくいとされた読み手は、文章を細かい単位に句切 って音声化していると考完た。

休止の持続懗間の度数分布は休止の持続時間を関数々 与る指数関数であるとみることがでさた。それ故、休止 の特微として、休止の持絖待間の出現頻度を刘数に变換 した時の回帰係数を Table 3-2 にあげた。この係数が 大きい程、長い休止が多くなることを意味する。この結 果から、聞きやすいと判断された偝及手 $(A, B, C)$ は 回帰係数が大きく、休止の時閒をより長くとっていると 教えられた。反対に、より聞きにくい諳み手（D，E，F，

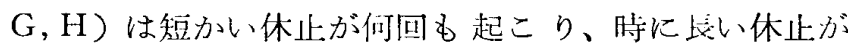
取られることがあるというような詿みうをしていると考 兄た。これは、聞きとり実験の結果、読んだ文章によっ て、順位の低い読み手の学読汶対与る聞きや与さの順位 が灾定しなかったことから、不安这な（规则性の少な い）読みすであると考完た。

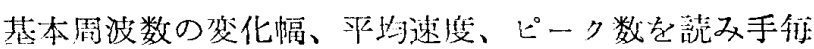
に算出した結果は Table 3-3の上らになった。それぞれ の测度の代表值を平均值に求め、散らばりをみるために 標準偏差をとった。これによると、ピーク值には読み手 の間の差が無く变化幅之平均速度との関係は $\mathrm{rs}=.98$ と 高かった。したがって、ピーク值は聞きやすさと関係し ないものとして测度から外した。変化幅と平均速度は测 度として独立ではなく、したがってどちらか一方で代表

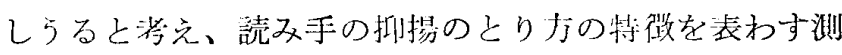
庭として基本周波数の平圤速度を観察した。Table 3-3

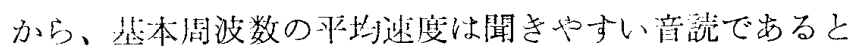
されたるの泟ど速いことが明らかであった。李た、基本

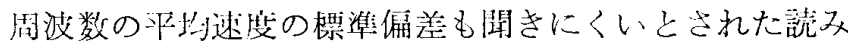

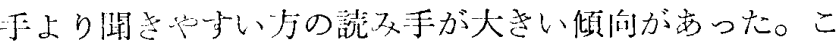

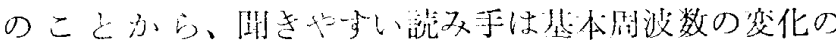

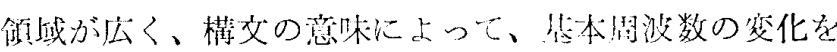
仕意化淍節していると洘穴られた。これに対して、聞き にくい者は变化领域が狄々、意味に応じた其本周波数の 調節をすることがなく、一本調子な読みうをしていると

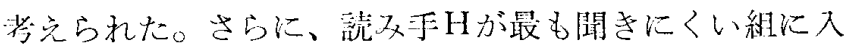

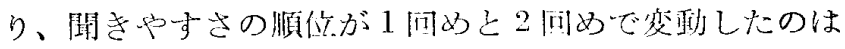

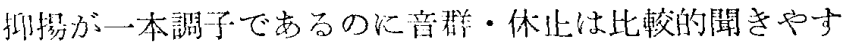
い゚ターンを示しているためと将兄られた。

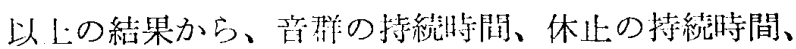

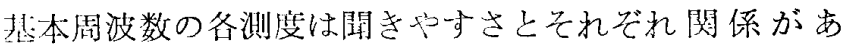
り、聞きやすさを测定する测度にできると考えた。しか し、人間は話しコトバをパターンとして受けとっている という立場に立つと、各測度の测定值は别々に处理され 
Table 3-1 The characteristic of sound group.

\begin{tabular}{lcccccccc}
\hline speaker & $\mathrm{A} * * *$ & $\mathrm{~B} * *$ & $\mathrm{C} * *$ & $\mathrm{D} *$ & $\mathrm{E} *$ & $\mathrm{~F}^{*}$ & $\mathrm{G}^{*}$ & $\mathrm{H}^{*}$ \\
\hline $\begin{array}{l}\text { average duration of } \\
\text { sound group }\end{array}$ & .12 & .08 & 15 & 07 & -.08 & -.03 & -.01 & .16 \\
S. D. & .31 & .25 & .28 & .27 & .28 & .24 & .29 & .28 \\
\hline
\end{tabular}

Table 3-2 The characteristic of pause.

\begin{tabular}{lcccccccc}
\hline speaker & $\mathrm{A}^{* * *}$ & $\mathrm{~B}^{* *}$ & $\mathrm{C} * *$ & $\mathrm{D}^{*}$ & $\mathrm{E} *$ & $\mathrm{~F}^{*}$ & $\mathrm{G}^{*}$ & $\mathrm{H}^{*}$ \\
$\begin{array}{l}\text { regression coefficient } \\
\text { of pause }\end{array}$ & -.17 & -.11 & -.20 & -.24 & -.36 & -.15 & -.18 & -.23 \\
\hline
\end{tabular}

( ) ; result of too long pauses eliminated.

Table 3-3 The characteristic of fundamental frequency.

\begin{tabular}{|c|c|c|c|c|c|c|c|c|}
\hline speaker & $\mathrm{A} * * *$ & $\mathrm{~B} * *$ & $\mathrm{C} * *$ & $\mathrm{D}^{*}$ & $\mathrm{E}^{*}$ & $\mathrm{~F} *$ & $\mathrm{G}^{*}$ & $\mathrm{H}^{*}$ \\
\hline $\begin{array}{l}\text { number of peak in Fo } \\
\text { mean }\end{array}$ & 2.8 & 1.18 & 2.36 & 2.56 & 2.23 & 1.83 & 1.75 & 1.71 \\
\hline S. D. & 1.96 & .81 & 1.07 & .93 & 1.04 & 1.25 & 1.22 & 1.16 \\
\hline range of $F_{O}$ & 131.45 & 88.0 & 135.68 & 83.94 & 92.91 & 73.17 & 45.0 & 41.86 \\
\hline S. D. & 65.26 & 41.35 & 42.31 & 18.27 & 25.42 & 35.73 & 26.78 & 26.63 \\
\hline $\begin{array}{l}\text { mean rate of Fo } \\
\text { contour in ramps }\end{array}$ & 360.15 & 225.87 & 382.09 & 19619 & 210.68 & 187.42 & 101.45 & 65.21 \\
\hline S. D. & 210.65 & 110.43 & 153.26 & 58.98 & 72.51 & 95.88 & 65.83 & 50.19 \\
\hline
\end{tabular}

るべきではなく、生しろ、超分節的なパターンとして、 一つのまとまった鱼を栵成し、それによって聞きやすさ が判断されると考光た。とこで、各変数の持つパターン と聞きやすさの网係を図式的に考察することにした。そ れによって、聞きやすさのア测を可能にするパターンの 特性を检詩した。

Fig. 3 に音保、休上のパターンと咸きやすさの媒係を

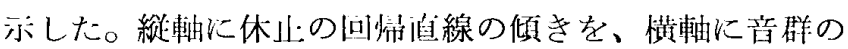

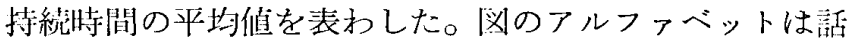
し手を赤した。音誈の材料として川意した原㭻の員の渡 り等によって生じた休止のような長すぎる休止は、その 人の本米の音読の特徽ではないとして計算から除外した とさ、回帰值線の傾きは破線のよ5に移動する㸃として 示された。このようにデータを処理した結果、聞きやす い䛃み手の組と聞きにくい組は戍の実線で围んだ部分に 分けられた。すなわち、望きやすい順に、A，B，C势 D群、F， G 群の 3 つの組化分類できた。しかし、E とHはこのパターンから逸脱して拈り、聞きやすささの順 位を休止:・音群のパターンとさせるデータ処理の方法か ら学测することはできなかった。聞きやすい音諳パター ソの特徵は、音群が長く、休止も長いことであったが、 Hのよ5に音群が長すぎても聞きにくくなると考えられ た。またEのように休止が短かくても比較的聞きやすい
組に入る望読もあった。したがって、音群と休忖を测度 としたパターンと聞きや导さは、有意な関係を持ってい

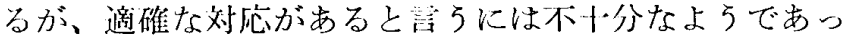
た。

Fig. 4には音群の持繶时間之基本間波数のパターンと 䦎きやすさの関係を示した。横軸に音群の持続特間を、 縦軸に基本周没数の平的速度を示した。平均速度の值が 大きいことは 1 秒当たりのイントネーションの変化が大 であることを示している。Fig. 4 に扣いて、最も聞きやす いと判断された読み手が示した帒を音読の示す最も理想 的な尛と仮定した後、最も聞きやすい読み手Aを中心と して同心归にパターンが分布すると仮定して、聞さや すさを点Aからのへだたりから尒测することを試みた。 この場合、各变数間の重みつけが間題となるが、各变数 の変化範囲が等しくなるように一応の重みづけを決める ことによって、らまく聞きやすさが予测できるようであ れば、この重みつけけは理学的に妥当であると考えるこ とにした。その結果、半径 $\overline{\mathrm{AC}} 、 \overline{\mathrm{AB}} 、 \overline{\mathrm{AD}} 、 \overline{\mathrm{AF}}$ 、 $\overline{\mathrm{AE}} \mathrm{E} \overline{\mathrm{AG}} \overline{\mathrm{AH}}$ の順に長くなっており、この半径の長 い読み手ほど聞きにくいと判断された者となった。すな わち、聞きやすさの心理的な决定は最も聞きやすい読み 手Aからのへだたりに対応していると説明できる結果を 得た。 


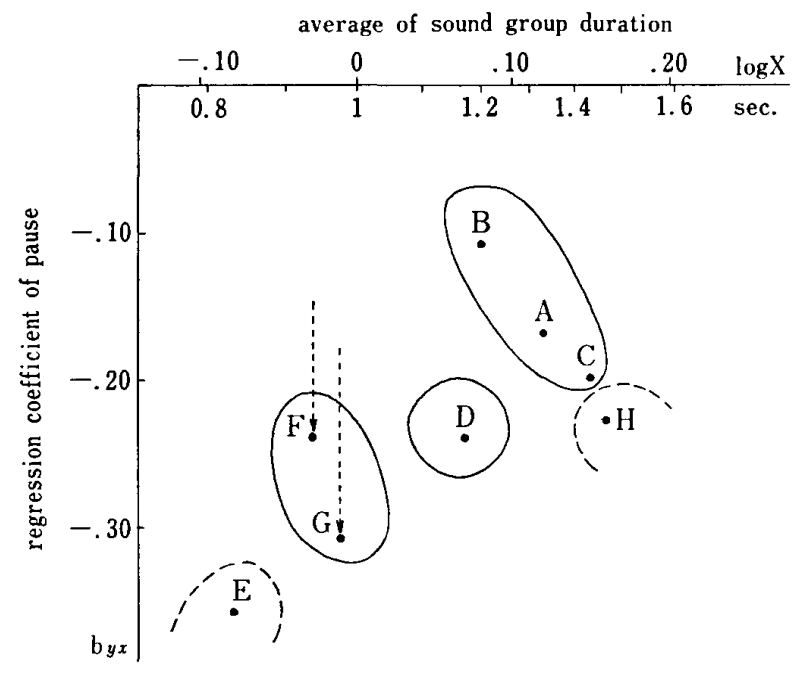

Fig. 3 Relation between the rank of easiness of hearing and the sound group-pause pattern.

Regression coefficient of pause was calculated by the frequency distribution of duration of pauses; $b=\frac{\sum x y}{\sum x^{2}}$

$y$; frequency, $x$; duration of pauses.

休止:の持總時間と基本周波数の平均速度の示すパター ンは Fig. 5 のよ弓に図示された。この図に招ても、音 群と基本周波数の平均速度と聞きや与さの閉係 (Fig. 4) と同粎、読み手Aのパターンからのへだたりうをもと に、聞きやすさの関係を求めた。すなわち、 $\overline{\mathrm{AC}}<\widehat{\mathrm{AB}}$ $<\overline{\mathrm{AD}}<\overline{\mathrm{AF}}<\overline{\mathrm{AE}}<\overline{\mathrm{AG}}=\overline{\mathrm{AH}}$ の順に半径は艮くな り、閒きやすさの順位と半径の長さが逆になっているる のも一譠あるが、聞きやすさの順位と半径の長さは高い

一致を示す結果が得られた。

そこで音群・基本周波数の平诗速度のパターンと休 此・基本周波数の平均速度のパターンが点Aを中心にし た倣弧の半径の関数として聞きやすさの順位と関係して いるかどうかを考察するために、聞きやすいと判断され た読み手の順位を縦軸に、点Aからの距離を横軸にプロ ットして、Fig. 4 と Fig. 5 の 2 つのパターンと聞きやす さの相関を求めた。Fig. 6 はとの結果を示し、アルフフ ベットは読み手を示した。Fig. 6 はこの場合の読み手の 聞きやすさのレベルを順序尺度で表わし、さらに読み手 の聞きやすさの順位を等間隔 $(1.0)$ と仮定した。そし て音群・基本周波数の平均速度のパターンを○印で示 し、休止・基本周波数の平均速度のパターンと聞きやす さの順位の関係は×印で示した。2つのパターンから得

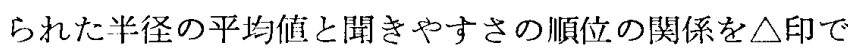
示した。この罒から、点Aからのへだたりと聞きやすさ の順位は、直線的な関係を持ち、相関が非常に高い結果

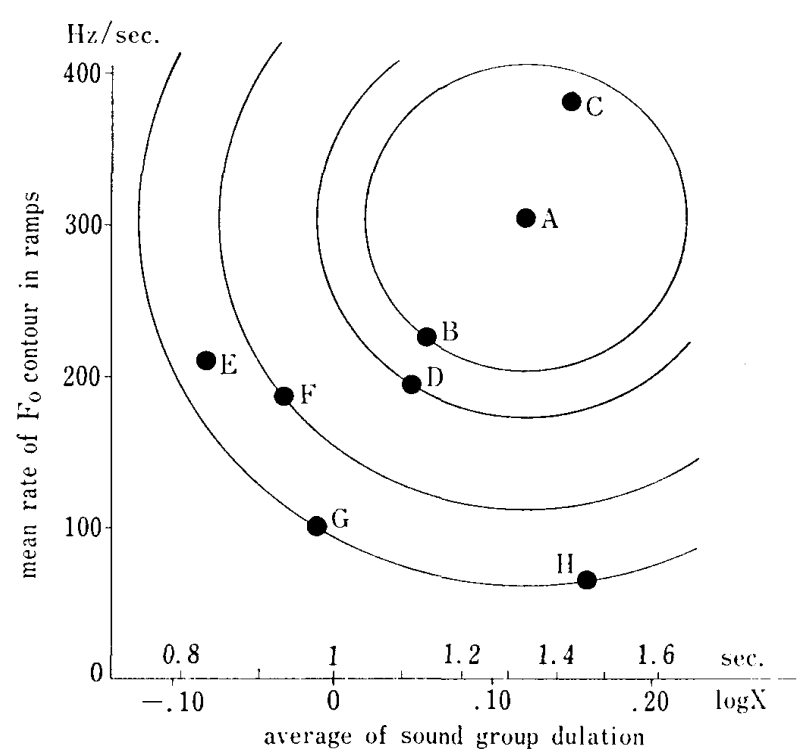

Fig. 4 Relation between the rank of easiness of hearing and the sound group-funda mental frequency pattern.

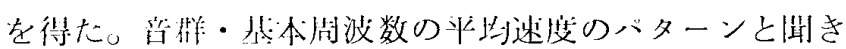
やすさの順位から得られたスピアマンの順位相网係数は $\mathrm{rs}=.95$ で、休业: ・壆本周波数の平均速度のパターンと 䦌きやすさの顺位から得られた伯は $\mathrm{r}_{\mathrm{s}}=.95$ であった。 この結果から、䦐きやすさは、最为闑きやすい常群・然

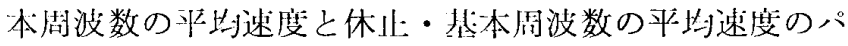
ターンを中心焦としたとき、そこからのへだたりとの閔 係で心理的に決められて拐り、人は判断然準として、そ のような情報処盟のう略を使用していると考えられた。

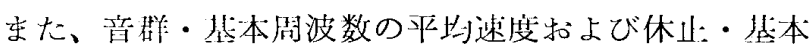

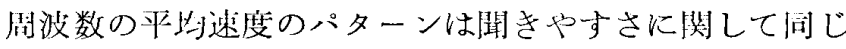
ような倾问を示していることから、間きやすさを悓盗す

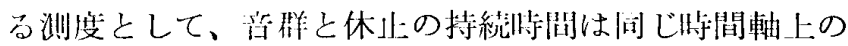
データであるから、笔全に独就した测度と考えることは むずかしい。一う、盟想的な音読であると仮定した読み 手Aの示した点は、この奏験だけから引き出された結果 であり、話しうの罢なる読及手が珫んだ場合にも同様の 品化なるかどうかは断言できない。しかし、少なくとも

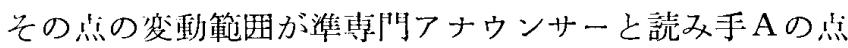
を含导师内に入るとすると、Fig. 5 では、理想としたパ ターンの変動が点 Bまで移動したとき、他の読み手の聞 きやすさを帒 B との距離で予测するとことはできない が、间じ条件のときFig.4では、他の珫み手の聞きや すさを点 Bを中心とした距離から予測することがきる。 また、2 種のパターンの示す点から得られた半径の平均 


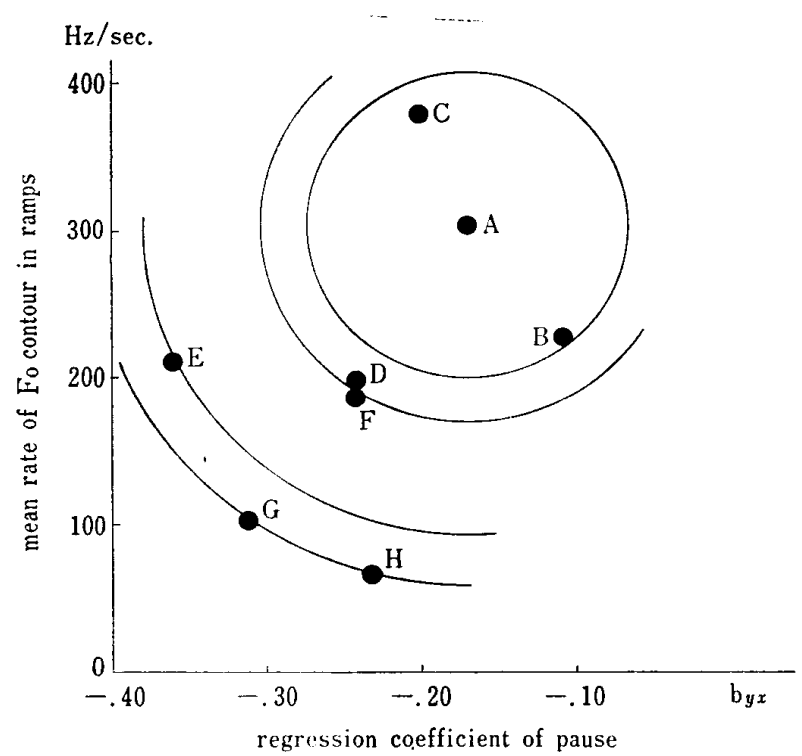

Fig. 5 Relation between the rank of eaeiness of hearing and the pause-fundamental frequey pattern.

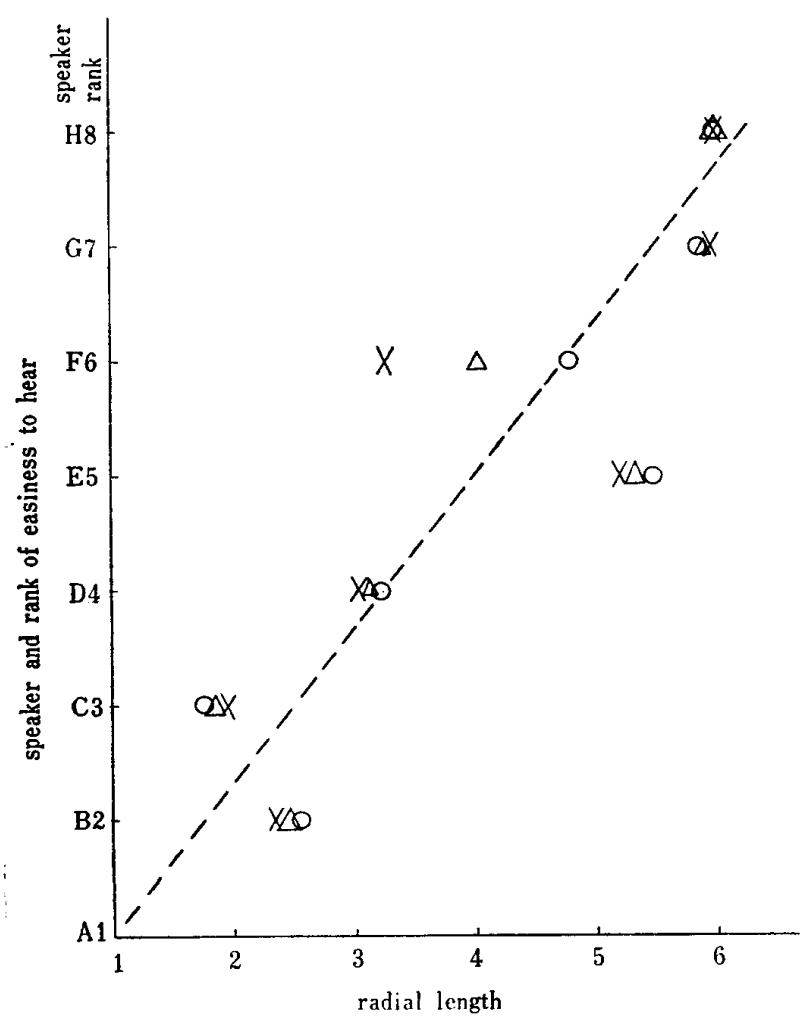

Fig. 6 Relation between radial length and rank of easiness of hearing.

$\bigcirc$ : the sound group-fundanental frequency pattern

$x:$ the pause-fundamental frequency pattern

$\triangle:$ the mean value of two patt erns
值で考学ると、半径 $\overline{\mathrm{AB}} \cdot \overline{\mathrm{AC}}$ と半径 $\overline{\mathrm{A} \mathrm{G}} \cdot \overline{\mathrm{AH}}$ の間に 有意だと見られる差がないので、音群・基本周波数の平 均值のバターンから予測できなかった B と Cの順位と、

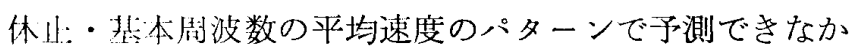
った $\mathrm{G}$ と Hの聞きやすさの順位が混同されやすく、聴取 実験の話し手に対する総合点の結果からもこのことがう なずける。この2 種のパターンから得られた半径の平均 值と聞きや少さとの相関は $\mathrm{rs}=.95$ と高い值を示した。 したがって、この実験の限定されたデータから、音群と 休止のいずれが測度としてょり有效に聞きやすさ影響 するかは䓂えない。むしろ、聞きやすさの判断には、こ れらの 2 つのパターンから得られるデータが相互に補い 合って影響を及济していると考兄られる。また、この䂺 笲では聞きやすさと超分節的な側面が閔係するかどうか を知ることを目的としたので、聞きやすさを泪できる ような具体的な変数間の重みづけを行なわなかった。こ のような作業を試みることは、さらに多くの䒠験データ によったときに始めて可能になると考完たからである。

\section{3. 笑験 III 分節之物理的要素の考察}

これまで、休止については、物理的な測定を主とし、 音䫓の伝える意味は取扱わないという立場から超分節倒 面として报ってきた。一方、P．Lieberman 4)によれ ば、岕いまいな文の粠造は、休止によって明確にされ得 ることが示唆されている。この上5に休止は文の境界 (boundary) や何の境界を明示することによって、文 章の構造を明確にする分節的な役割をも果していると 考えられる。したがって、文章構造を明確にするような 意味の们切りがとられている音読の方が、そうでない音 詐よりる聞きやすいだろらと仮定できる。そこで、聞き やすい音読のグループ（上位 3 人）と聞きにくい音読の グループ（下位 3 人）の間で休止のとりお差があるか ぞうかを検詩した。休止の起こる位置は文、文節、名詞 们、接絖间のところであったので、それぞれの位置で起 こった休川:の持綿㭙閆の平均老測度とした。

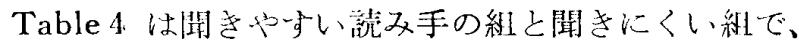
间じ文を㜔んだときの、それぞれの位置で起こった休止 の持続時間と、文の休止を1 としたときの、その他の们 や単語等での何划りの比を示したものである。聞きやす い読み手の組は聞きにくい組上りも文と文の間の休止に 况した時間が句等の休止に費した時间よりも長かった。 聞きやすい組では文と文の間の休止に対するとの他の休

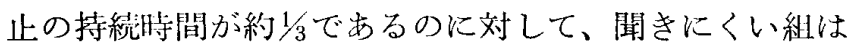
文の間以外の休止が全く無かったり、文の間の休止との

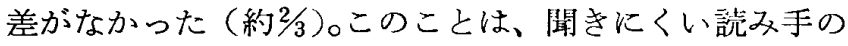
組では、交や句に対して、休止による重みづけをしない 
ために、文の構造や文と文の関係を明確にする手がかり を欠いたと考它られる。このよ5な音声の連続（音読） を聞く場合、聞き手は文の関係を、むっばら、音韻を手 がかりに得なければならない。したがって構文形式等に 関する情報がそれだけ少ないので分節を構成与るための 聞き手の負担が多くなり、聞きにくいと判断されたと洘 える。
与さの順位との対伈関係を求めた。さらに、文、節など の分節的側面々超分節的側面である休止の関係を求める ことによって、超分節的側面と分節的側面の関倸を求 め、霉語に扣ける超分節的側面の役割を考虑する必要が 茜るかどうかを考察した。

その結果、聞き手は聞きやすさの順位を一対比較法に よって求めることができ、その秤価のし方の個人差は非

Table 4 Syntactic boundary and duration of pause in two groups of speakers.

\begin{tabular}{c|cccc|cccc}
\hline & \multicolumn{3}{|c|}{ duration of pause occured (sec.) } & \multicolumn{4}{c}{ pause/pause after a sentence } \\
speaker & \begin{tabular}{c|cccc|cccc} 
after a \\
sentence
\end{tabular} & $\begin{array}{l}\text { after a } \\
\text { clause }\end{array}$ & $\begin{array}{l}\text { after a } \\
\text { noun } \\
\text { phrase }\end{array}$ & $\begin{array}{l}\text { after a } \\
\text { conjunc- } \\
\text { tion }\end{array}$ & $\begin{array}{l}\text { after a } \\
\text { sentence }\end{array}$ & $\begin{array}{l}\text { after a } \\
\text { clause }\end{array}$ & $\begin{array}{l}\text { after a } \\
\text { noun } \\
\text { phrse }\end{array}$ & $\begin{array}{l}\text { after a } \\
\text { conjunc- } \\
\text { tion }\end{array}$ \\
\hline A & 1.03 & .31 & .29 & .34 & 1 & .30 & .28 & .33 \\
B & 1.53 & .70 & .61 & .36 & 1 & .46 & .40 & .24 \\
C & 1.30 & .48 & .25 & .30 & 1 & .37 & .19 & .23 \\
F & 1.02 & 0 & .41 & 0 & 1 & 0 & .40 & 0 \\
G & .60 & .55 & .38 & .59 & 1 & .92 & .63 & .98 \\
H & .80 & .49 & .40 & .41 & 1 & .61 & .50 & .51 \\
\hline
\end{tabular}

このことから、音読の聞きやすさのパターンは意味的 侧面と密接に結びついていると考觉られた。そして、こ の奉験結果による限り、意味の伝達上の効果はイントネ ーション、休止、音群等を観点として、推定することが できると考えられる。イントネーションは単調（平均速 度が小さい）であるより变化のある万が、休止は文と節 の位置でより非くとられた方が、音群は構文の単位でよ り韦い方が、聞き手に意味をよく伝えることができ、そ 5いう音読能力を持つ人は高次の伝達手段を身沈つて いると考えることができる。

これらの実験結果から、イントネーション等の超分節 的側面は構文形式や意味的まとまりを伝達する媒体の役 割をになっているので、聴筧障害児等にこれらの要菜の 存在を適格化認識させることが害語における構文規則の 存在を認識させる基礎を提供することなるのではないか と考える。すなわち、普通見の言語獲得が音韻等の分節 的要素だけでなく、意味的側面と密接に結合した構文形 式の音声言語によってなされると考乓ると、聴覚障害㫛 等に対与る言語指導の過程に括いて、このようなイント ネーションや音群等に相当した情報量の存在を認知させ ることが必要であると考える。

\section{IV 結 言}

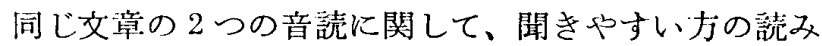
手を、聞き手に指摘させることによって、各読み手の聞 きやすさの順位を求めた。亦た、イントネーション、音 群、休止に関する分析によって、超分節的要素之聞きや
常に小さいと考学られた。音群・基本周波数の平均速度 の示すパターンと休止・基本周波数の平均速度の示すパ ターンはそれぞれ、聞きやすさと高い相関を持ち（音 群・基本周波数の平均速度と聞きやすさの相関、休止・ 基本周波数の平灼速度と聞きやすさの相関 $(r s=95)$ 聞 きやすさを規定する測度として認め得た。また、超分節 的側面である休止と分節との関係に考察を加えた結果、 統語的に高次な単位に拉いてより長い休止が起こった方 が聞きやすいと判断されたことから、休止は構文の境界 （boundary）を示す大きな役割を果していると考えるこ とができた。すなわち、休止の大小が意味的な分離の程 度と関係している上ろだった。それゆ古、休水で句切ら れる音群を一発話の意味的単位とし、休心にはさ亲れた 部分をイントネーションや音群の分析の測定単位とし て、分析したことは妥当であったと考光得た。したがっ て、滳能訓練や言話指導の際に、言語的コミュニケーシ ヨンは意味的単位を一群として伝達する動作であると仮 定し、聞きやすい材料を選んだり、発話の効果的な伝達 力法の指導を意因するとさは、上述の上うなパターンに

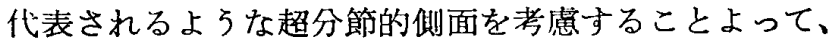
より効果的に行ないらると考光た。

すなわち、「聞きやすい音䛨」として漠然と判断し、 分類しているにもかかわらず、そこには、伝羍可能な物 理的要素（音群、休止、基本周波数）が存在し、それが 分節的な文の何切り、句構造の明膫化と結びついている のであるから、㸗語力の低い者にとって重要な伝達要素 
として作用していると考えざるを得ないである5。

ぬた、須藤等、Williams 等、Goldman-Eisler, Lie-

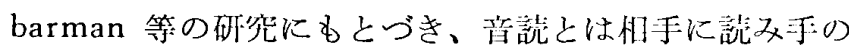
意味解釈を伝えるために行ならコミュニケーションの于 段であると考劣るとき、同一の構文を与劣たにもかかわ らず、長い音群、垃い休止、大きい閏波数の平均速度之 い5特徽を持つ音誥が聞きやすかったことから将えて、 音珫の超分節的パタ-・ンは、意味解釈1:の手がかりとな る情報をより多く方をているように思われる。すなおり、

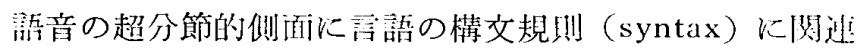

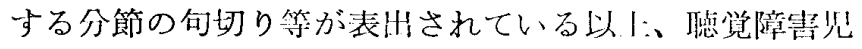
等の言語指導の際にそのような侧面を視覚あるいは残蚛

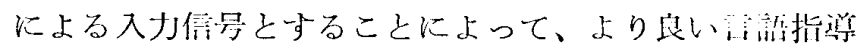
ができるのではないかと考える。

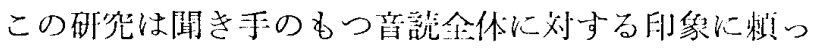
た分析であり、㜔み手が文章をどのような単位に㩐成し、 意罒的に伝達しようとしていたかは检䚯していない。し

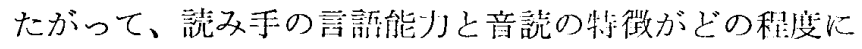
閂係があるかしいう閌題が今後の課起として残されてい る。ナなわら、音沇は話し手の意味解积の結果を村手に 伀えるための表現手段であると考えたとき、読み乎が非 解しないまま読む文章は、読名手によって、音辣を兴位 よする記号列を意味するにすぎない。したがって、無意 味音節を㜔を時のように皆韻 1 つつに间じ重みづけを するため、ひろい読みの状熊に此まるだろらと考えられ る。一少、文章を読さ能力のある者はコーディングしや すい意味の単位で句切りを入れたり、あいまいさを耤け るためにイントネーションを付加する操作をすると洘え られる。したがって、この音読能力と超分節的側面の掓

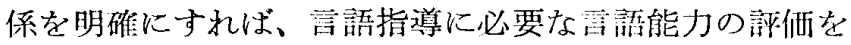
音読という手続により、超分節的要素を测度として测送 可能であるかどうかを確かめ得ると考学られる。

さらに教察をすすめると、文字によって伝迋される情 報量が音苼言語によって伍達される情報量よりも少ない

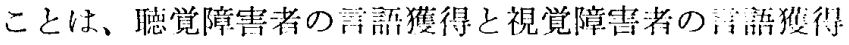
を比較した場令いっそう明碓になる。このことは、文ら

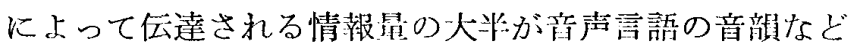
の分節に相监与ると考方ると、分節们要素で伝播与る情

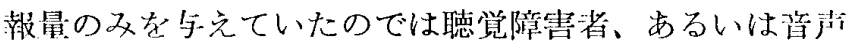

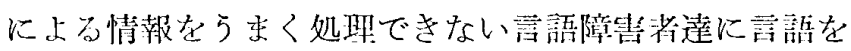
快常に獲得させることが困難であることを意味すると体 えられる。特に、これらの障㫪者はシンタックスの獲得 が難しいことが臨床的に明らかにされている。一方、こ の研栄の実験 III では、文字に表記されていない休止や音 群という超分節的要素がシンタックスを明示す手がかり
となり得ることが州らかにされた。そ扎的え、罗在、

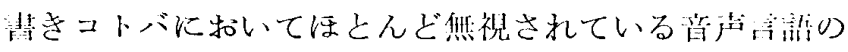
超分節的な侧面に、シンタックスに関する情献を伝播 させ、獲得させる媒体を求めなけ机ばならないと浇光 る。

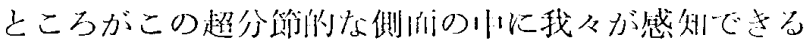

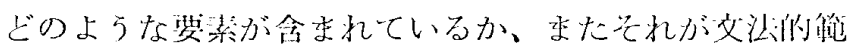

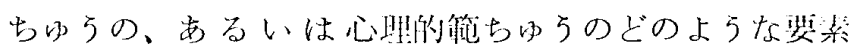

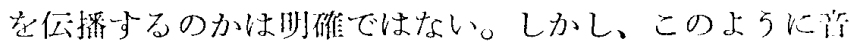

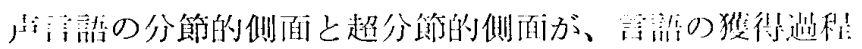
に関係すると考光るならば、それがコミュニターション 行動の川で、どのような性組にしたがって進川され、ど

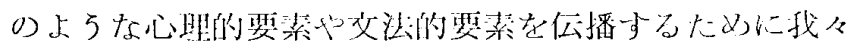
の、活䓝得がう要くいったのか老近似似にでも分析し、

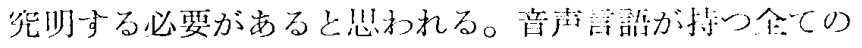

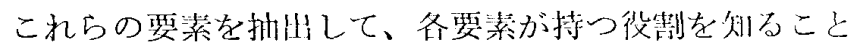

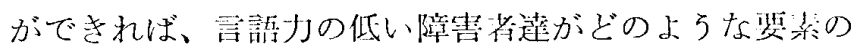

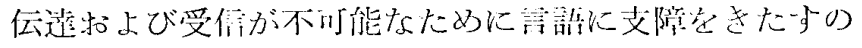

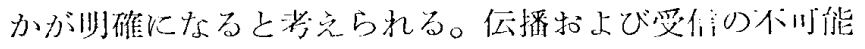

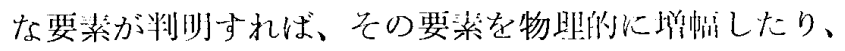

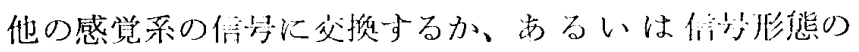

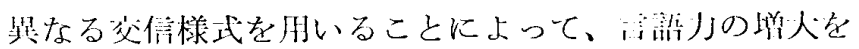

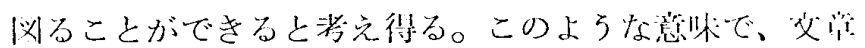

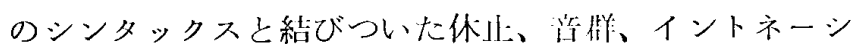

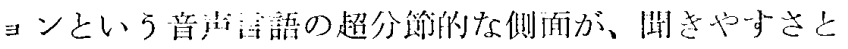
い5心非的な感筧をひき起こす煤休となっているといら 結果を得たことは、少なくとも、イントネーション等の

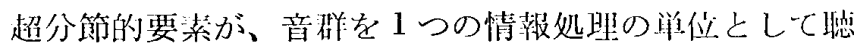
收しやすくする手がかりを与えるための音声们号として

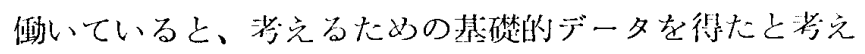
られよう。

\section{参考交 献}

1) Menyuk, P. : (1969) Sentences Children Use M.I.T. Press.

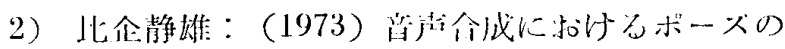

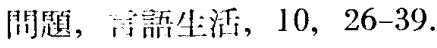

3) Goldman-Eisler, F. : (1958) Speech analysis and mental process, Langnage and Speech, $1,59-75$.

4) Lieberman, P. : (1968) Intonation Perception and Language, M.I.T. Press.

5) 須藤貢明, 保坂真琵：(1975) 平叙文. 間疑文・ 感嗼文のイントネーションによる升別，特殊教 奇学研究，13，24-35 


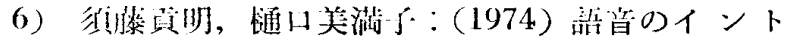
ネーションと感情, 日本特殊教育学会第12回大 会発表論文集, 104-105.

7) Willams, C.E. and Stevens, K.N. : (1972), Emotions and speech, J.A.S.A. 52, 4, 1238 -1250 .
8）滕田尚：(1970) アナウンスに打ける高低抑掦， NH K技術研究，51-62.

9) Lehiste, : (1970) Suprasegmentals, M.I.T. Press.

10）高橋眞由美：(1975）朗読・談話を伝垟する物理 的側面, 特殊教育学研究, 12 44-51.

(1975. 4.5 受) 
Jap. J. Spec. Educ., 13, 2, 1975.

\title{
ACOUSTIC CORRELATIONS OF SUPRASEGMENTAL FEATURES
}

\section{AND THE EASINESS OF HEARING OF ORAL READINGS.}

\author{
* MAYUMI TAKAHASHI, TSUGUAKI SUDO, HITOSHI OGAWA $\Lambda$ ND SHUNJI TANI \\ (Tokyo-Gakugei University)
}

This paper describes some further attempts to identify and measure some parameters in the speech signal that reflects the easiness of hearing for the listener.

From some literatures this psychological perception assumed to be constructed by suprasegmental informati ons and linguistic informations. Though such suprasegmental parameters can be supposed to be inherent in speech, they have been ignored on the speech therapy in Japan. Therefore three experiments were projected to study some psychological aspects in speech signal, with these parameters. Various 10 minutes recordings were obtained from the readings of a professional announcer, two semiprofessional announcers and 5 students by reading a literature. Excerpted portions of these readings were subjected to hearing tests and a segmental analysis, and all portions of them were subjected to study some psychological aspects in speech signal.

Procedures

Exp. I. Hearing test: We saw whether the two excerpted portions can be defined the ranks of the easiness to hear of oral readings for several listeners. Seven normal adults were asked to judge whether one of the $30-50$ sec. oral readings had the easiness of hearing or another. Each test trial was 28 randomly arranged oral samples by the method of paired comparison. Exp. II. Acoustic analysis: Suprasegmental features were obtained from some parameters of oral readings. Oral samples which 8 speakers read for $10 \mathrm{minu}$ ites were ana lysed into a duration of sound groups, and a pause. Further, each sample in Exp. I. was analysed into a fundamental frequency (Fo) contour in ramps. Acoustic correlatinos were obtained from the patterns which consited of these suprasegmental parameters and the easiness to hear of the samples. Exp. III. Segmental analysis: To confirm the suprasegmental features carry a information with regard to the linguistic content of a message was examined in a segm ental analysis.

\section{Results}

1. There were clearly the differences of the easiness to hear of oral sample readings. (Tab. 2)

2. The differnces were matched very good to the pattern consisted of the suprasegmentals in oral readings. (Fig. 6 )

3 Most long pauses were occured at the end of the sentences. ('Tab. 4)

\footnotetext{
* Department of Specch and Hearing Education for Infants at Sozen Primary School Hiratsuka City Kanagawa Prefecturc
} 